\title{
CD159 Family
}

National Cancer Institute

\section{Source}

National Cancer Institute. CD159 Family. NCI Thesaurus. Code C123802.

A family of cell surface receptors found on natural killer cells and some T-lymphocytes

that both interact with MHC class I HLA-E molecules and modulate cell-mediated

cytotoxicity. There are two CD159 proteins, NKG2-A/NKG2-B type II integral membrane protein and NKG2-C type II integral membrane protein. 